\title{
OECDpublishing
}

\section{WEST AFRICAN FOOD SYSTEMS AND CHANGING CONSUMER DEMANDS}

\section{WEST AFRICAN PAPERS}

December 2016 No. 04 



\section{WEST AFRICAN FOOD SYSTEMS AND CHANGING CONSUMER DEMANDS}

This paper has been prepared by

JOHN STAATZ

Professor Emeritus, Department of Agricultural, Food and

Resource Economics, Michigan State University

FRANK HOLLINGER

Economist, Investment Centre Division (TCIA), Food and

Agriculture Organization of the United Nations (FAO)

This paper is published by

The Organisation for Economic Co-operation and Development and

The Food and Agriculture Organization of the United Nations 


\section{WEST AFRICAN PAPERS}

The West African Papers series is designed to share studies with a wide audience of specialists, practitioners, decision-makers and the informed public. The series explores the nature, dynamics and characteristics of African social, economic and political transformations from a regional and multidisciplinary perspective. It seeks to stimulate discussion and gather information to better anticipate the changes that will shape future policies. Papers are available in English and/or French, and summaries are available in both languages. Initiated by the Sahel and West Africa Club (SWAC) to highlight and promote West African issues, the work presented is prepared by its Secretariat, Members and partners; other OECD departments; related international organisations; and associated experts.

For more information on the Sahel and West Africa Club: www.oecd.org/swac

Please cite this publication as:

Staatz, J. and F. Hollinger (2016), “West African Food Systems and Changing Consumer Demands", West African Papers, No. 04, OECD Publishing, Paris.

http://dx.doi.org/10.1787/b165522b-en

Author contact: Frank.Hollinger@fao.org and staatz@anr.msu.edu

ISSN 2414-2026

OECD Working Papers should not be reported as representing the official views of the OECD or of its member countries, or of FAO or its members. The opinions expressed and arguments employed are those of the authors.

This document and any map included herein are without prejudice to the status of or sovereignty over any territory, to the delimitation of international frontiers and boundaries and to the name of any territory, city or area.

The designations employed and the presentation of material in this information product do not imply the expression of any opinion whatsoever on the part of the Food and Agriculture Organization of the United Nations concerning the legal or development status of any country, territory, city or area or of its authorities, or concerning the delimitation of its frontiers of boundaries.

Working Papers describe preliminary results or research in progress by the author(s) and are published to stimulate discussion on a broad range of issues on which the OECD works. Comments on Working Papers are welcomed, and may be sent to the Sahel and West Africa Club, OECD, 2 rue André-Pascal, 75775 Paris Cedex 16, France.

Authorised for publication by Laurent Bossard, Director, Sahel and West Africa Club Secretariat (SWAC/OECD). 


\begin{abstract}
Fueled by a burgeoning population, urbanisation and income growth, West African food demand is rapidly transforming, with striking increases in total quantities demanded, growing preference for convenience, diversification of diets towards more perishable products, and an increased concern for product quality. These changes provide great opportunities for the West African food system to increase production, value added, job creation and food security. Yet a number of structural and policy constraints continue to threaten the ability of West Africa to seize these opportunities. This paper analyses the key drivers of change and their implications on the various demands facing the food system. It then looks at how different elements of the food system respond to evolving demands, discusses the constraints to more effective responses, and finally considers some policy implications and key recommendations, particularly in the context of the ECOWAS-led efforts to develop and implement more effective regional agricultural policies.
\end{abstract}

Keywords: food systems, food policy, food demand, agricultural transformation, West Africa JEL classification: N57, Q13, Q18, R11, R58

\title{
RÉSUMÉ
}

Sous l'effet de la pression démographique, de l'urbanisation et de la croissance des revenus, la demande alimentaire des ménages ouest-africains se transforme. Ceci se manifeste par de fortes augmentations des volumes, une demande croissante pour la praticité des aliments, une diversification vers des produits périssables et une préoccupation grandissante pour la qualité des produits. Ces transformations offrent des opportunités pour l'Afrique de l'Ouest en termes de croissance de la production, de création de valeur ajoutée et d'emplois, et de sécurité alimentaire. Des contraintes structurelles et politiques pourraient cependant empêcher la région d'en profiter pleinement. Cet article présente les principaux facteurs de ces changements et leurs implications sur l'évolution de la demande. Il analyse ensuite les réponses des différents éléments du système alimentaire et les obstacles auxquels ils sont confrontés. Il aborde enfin les implications et émet des recommandations, en particulier dans le cadre des initiatives de la CEDEAO pour développer des politiques agricoles régionales plus efficaces.

Mots clés : systèmes alimentaires ; politique alimentaire ; demande alimentaire ; transformation agricole ; Afrique de l'Ouest

Classification JEL : N57 ; Q13; Q18 ; R11 ; R58 


\title{
NOTE FOR READERS
}

This paper draws heavily on results from Agricultural Growth in West Africa (AGWA): Market and Policy Drivers (African Development Bank and FAO, 2015) which the authors co-edited. The full report is available at: www.fao.org/3/a-i4337e.pdf (English version) and www.fao.org/3/a-i4337f.pdf (French version).

In this article, the term "West Africa" refers to the ECOWAS zone, which includes 15 member states: Benin, Burkina Faso, Cabo Verde, Côte d'Ivoire, The Gambia, Ghana, Guinea, Guinea-Bissau, Liberia, Mali, Niger, Nigeria, Senegal, Sierra Leone and Togo. The term food systems refers to the full range of activities, "from seed to table" involved in the production, processing, marketing and processing of food.

\begin{abstract}
ABOUT THE AUTHORS
John Staatz is Professor Emeritus in the Department of Agricultural, Food and Resource Economics at Michigan State University. Frank Hollinger is an Economist at the Investment Centre Division (TCIA) of the Food and Agriculture Organization of the United Nations (FAO). The authors gratefully acknowledge the very helpful comments of Thomas Allen, Lia Beyeler, Philipp Heinrigs and Ousman Tall on an earlier draft of this paper but accept full responsibility for any remaining errors of fact and interpretation.
\end{abstract}




\section{TABLE OF CONTENTS}

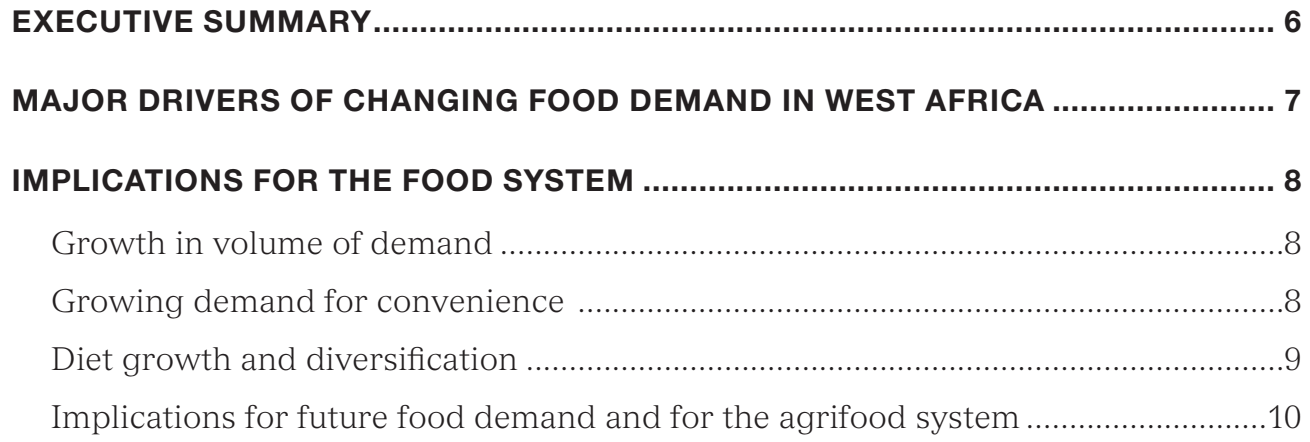

\section{FIGURES}

Figure 1. Contribution of area and yield to output growth in cereals, 1980-89 to

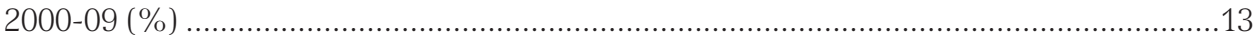

Figure 2. Allocation of Senegal's NAIP by programme (2011-2015) ..........................17

\section{TABLES}

Table 1. Percent of maize expenditures on unprocessed vs. processed grain

Table 2. Average income elasticities of demand for selected food products from budget consumption studies in West African countries

\section{BOX}

Box 1. West Africa's unfinished cassava revolution 


\section{EXECUTIVE SUMMARY}

emand for food in West Africa is rapidly transforming, driven by strong population growth, urbanisation, rising incomes and changing consumer preferences. Consumers increasingly rely on markets and look for foods that are convenient to buy, prepare and consume - an overarching trend which cuts across all countries and income groups in the region. As a result, diets are more diversified, with rising intake of highervalue perishable and processed products. At the same time, there are increasing concerns about food safety, quality and healthfulness. The response of the various components of the food system to these changes has been mixed. Although agricultural production grew vigorously since 1980, demand outpaced production, resulting in increased imports. Most agricultural value chains remain plagued by poor co-ordination, underdeveloped marketing and transport infrastructure, and erratic electricity supplies. These factors drive up risks and costs facing value-chain actors and limit the transmission of information and incentives from consumers to producers. Given these weaknesses, retailers and wholesalers often revert to imports to meet urban demand.

Dominated by traditional marketing channels, the retail system has responded by greatly expanding both the number of retailers and the scope of their activities, yet it struggles to cope with the burgeoning growth of demand.

This growing and increasingly diverse food market provides greater opportunities for the West African food system to increase production and value added, thereby generating more jobs, income and food security. The policy response has been more co-ordinated and regionally consistent than previous efforts, giving agricultural development greater visibility in the political agenda of many West African countries. Yet a number of structural and policy constraints continue to threaten the ability of the region to seize these opportunities. Most investment programmes have placed insufficient emphasis on the post-harvest segments of the food system and paid too little attention to food products for which demand is growing fastest. Policies in the region need to adjust to the ongoing transformation to provide the framework for the development of the West African food economy. Below are six key elements to address these challenges:

1. Increase the level of public investments in agriculture up to the CAADP target of $10 \%$ of the government budget and improve the investment mix, with a stronger emphasis on post-harvest segments of the food system.

2. Strengthen rural-urban linkages and intraregional trade by prioritising investments in transport and marketing infrastructure to improve market access and value addition, reduce post-harvest losses and expand input markets and support services in rural areas.

3. Deepen regional integration to increase the scale economies and improve the international competitiveness of the region's food products.

4. Build the skills base necessary to transform West Africa's food system into a modern driver of economic growth.

5. Improve policy co-ordination and harmonisation between sectors, actors and along different levels of government, from supra-national to local levels.

6. Improve policy implementation, investing in the capacities of key agencies and organisations charged with implementation, as well as ensuring the overall coherence of policies and programmes. 


\section{MAJOR DRIVERS OF CHANGING FOOD DEMAND IN WEST AFRICA}

W

est Africa is highly diverse in terms of country size, population densities, agroclimatic conditions, natural resource endowments and economic policies, as well as linguistic, historic and cultural dimensions. Despite these differences, several broad drivers and trends are shaping consumer demand for food in the region. These include:

- Strong population growth. Although a number of authors (e.g. Hitimana et al., 2009; Potts, 2009; Potts, 2012), have questioned the accuracy of official demographic and urbanisation statistics, the broad trends for the region are clear. UN projections indicate that the population of ECOWAS countries is expected to more than double between 2015 and 2050, rising from 349 million to 789 million (UNDESA, 2015). ${ }^{1}$ Much of this population growth will occur in the coastal countries, where population densities are 6 to 15 times higher than in the Sahelian states.

- Rapid urbanisation and migration. West Africa has experienced explosive urban growth since 1950, with the number of urban residents increasing by a factor of 30 , from 5 million in that year to 150 million in 2015. With 43\% of its population living in cities (Allen and Heinrigs, 2016), West Africa is the most urbanised region of Sub-Saharan Africa. While metropolitan areas are the main interface with global markets, small cities and towns are the main interface with the rural economy and serve as a means by which urban food habits spread into rural areas.

- $\quad$ Youth bulge. The population is predominantly young, with 44\% below the age of 15 (UNDESA, 2015). This youthful population, increasingly urban and plugged into digital media, is adopting new lifestyles and changing food consumption patterns, spreading different modes of consumption from metropolitan areas into the hinterland. In addition to boosting the demand for additional and new types of food, the youth bulge is also fuelling the demand for new and rewarding jobs.

- Growing incomes, but still strong income disparities. West Africa, like much of the developing world, has seen markedly improved economic progress since the mid-1980s (Radelet, 2015). GDP per capita in the ECOWAS zone grew at an average annual rate of $3.8 \%$ over the period 2000-15, with all countries of the region except Liberia experiencing positive per capita GDP growth during that period (World Bank, 2016). As West African economies have grown, the middle class has expanded. The African Development Bank (AfDB, 2011b) defines the middle class as individuals or families earning more than USD 2/capita/day (in 2010 dollars). In 2010, 25\% of West Africa's population met that definition, accounting for roughly 70 million people. Yet, $53 \%$ of these people fall into what the AfDB calls the "floating middle class", defined as people with per capita incomes of between USD 2 and USD 4 per day. The middle class is concentrated in the three largest countries: 50\% live in Nigeria, with an additional 27\% in Côte d'Ivoire and Ghana. However, the countries with the highest share of their population in the middle class are Ghana (47\%), Cabo Verde (46\%), Côte d'Ivoire (37\%) and Senegal (36\%).

- Growing reliance on the market for food. As the population has urbanised and as rural economies have diversified, West Africans have become increasingly reliant on markets rather than home production as their main source of food. Reardon et al. (2015) estimate that between two-thirds and three-quarters of all food (in value terms) consumed in West Africa now passes through markets. These market transactions in the food economy were estimated to total USD 126 billion in 2010 (Allen and Heinrigs, 2016). 
- High share of income spent on food. Despite the growth of the middle class, $75 \%$ of the West African population continues to live at under USD 2 per day. Consequently, consumers spend a large proportion of their income on food, ranging on average from 39\% in Côte d'Ivoire to 65\% in Nigeria. They are therefore highly sensitive to increases in food prices.

- Changing tastes and preferences. Urbanisation, migration, and broader exposure to electronic media have led to a broadening of food habits, ranging from greater consumption of processed cassava products in the Sahelian countries to the spread of Western-style fast food in some of the larger urban areas. Some of these changes (e.g., expanded consumption of poultry meat in the coastal states) has been facilitated by the availability of cheap imported food products. At the same time, with rising incomes and education, there are also increasing concerns among some segments of the population about the links between diet and health, creating a demand for healthier food products.

\section{IMPLICATIONS FOR THE FOOD SYSTEM}

A s a consequence of the drivers discussed above, demand for food in the region is rapidly growing and changing. The most striking changes are an increase in total quantities demanded, a growing demand for convenience, a diversification of diets towards more perishable products, and an increased concern about various aspects of product quality, including cleanliness and healthfulness.

\section{Growth in volume of demand}

The growth in population and per capita incomes is fuelling a rapid growth in the total volumes of food demanded in the region. Total population is estimated to grow at $2.5 \%$ per year between 2015 and 2020, slowing only to 2.1\% per year between 2035 and 2040.2 Assuming an annual GDP per capita growth rate of $3 \%$ through 2020, and an average income elasticity of demand for food to be 0.7 , this implies that the volume of food available will need to grow by a minimum of $4.6 \%$ per year through $2020 .^{3}$

\section{Growing demand for convenience}

Demand for convenience - foods that are quick and easy to prepare and consume - is an overarching trend cutting across all countries and income groups. Increasingly pressed for time, consumers are willing to pay for others in the food system (processors, streetfood vendors) to carry out some or all of the food processing and preparation for them, leading to rapidly growing demand for post-harvest activities in the food system.

The demand for convenience and its links to both income growth and urbanisation are illustrated in Table 1, which shows the percentage of consumer expenditures on unprocessed vs. processed maize (e.g. flour) in five West African countries, in both rural and urban areas, during the mid-2000s. In every country, urbanites devoted a higher percentage of their expenditures on processed maize products than did their rural counterparts. More striking, as average incomes increased across countries, the expenditures on processed products dramatically increased. Whereas over $98 \%$ of expenditures on maize in rural Niger were for unprocessed grain, city dwellers in Côte d'Ivoire devoted over 84\% of their maize expenditures on processed products. The demand for convenience extends to manufactured foods. The processed food for which demand grew the fastest in Nigeria over the period 1998-2011 (at over 11\% per year) was Asian-style instant noodles — a food that is cheap and which can be prepared quickly by just adding boiling water. 
Table 1

Percent of maize expenditures on unprocessed vs. processed grain

\begin{tabular}{|c|c|c|c|c|c|}
\hline \multirow[t]{2}{*}{ Country } & \multirow[t]{2}{*}{ Year } & \multicolumn{2}{|c|}{ Unprocessed grain } & \multicolumn{2}{|c|}{ Processed/prepared } \\
\hline & & Urban & Rural & Urban & Rural \\
\hline Niger & 2005 & 92.5 & 98.3 & 7.5 & 1.7 \\
\hline Mali & 2006 & 81.9 & 92.9 & 18.1 & 7.1 \\
\hline Burkina Faso & 2009 & 78 & 93.2 & 21.9 & 6.8 \\
\hline Ghana & 2006 & 31.2 & 48.3 & 69.8 & 51.7 \\
\hline Côte d'Ivoire & 2008 & 15.6 & 23.2 & 84.4 & 76.8 \\
\hline
\end{tabular}

Source: Hollinger and Staatz, 2015

\section{Diet growth and diversification}

West Africa's food demand is becoming more diverse, mirroring similar trends in other developing regions. Food demand is evolving from undifferentiated bulk commodities prepared at home towards food products with differentiated quality attributes such as cleanliness, shelf-life, cooking time, freshness, nutritional content, packaging, labelling and presentation. While price remains a key determinant of demand for the large majority of the population, other product attributes are gaining importance in consumers' purchasing decisions. The trend towards dietary diversification is especially marked in large coastal countries and urban areas, but also spreading to inland countries, smaller towns and rural areas.

Analysis of data from food balance sheets over a 30-year period (1980-2009) as well as information from budget consumption studies carried out in the 1990s and 2000s document this diversification as well as a striking increase in overall food availability as incomes have grown and the population has become more urbanised (Bricas et al., 2013; OECD/ SWAC, 2013). Among the most apparent trends are the following:

- Increased per capita calorie and protein availability. All ECOWAS countries except two experienced increases in caloric availability per capita between 1980 and 2009, a few (Burkina Faso, Ghana, Mali and Nigeria) by up to 50\%. Per capita protein availability also increased in most countries, in part because much of the protein consumed is cereal-based and cereal consumption was rising in most countries. In addition, several countries also experienced increases in per capita availability of animal-based protein.

- Diversification among starchy staples. Although starchy staples (cereals, roots and tubers) continue to account, on average, for between two-thirds and threequarters of the calories in West African diets, there has been diversification of these carbohydrate sources. The substitution of rice and to a lesser extent, wheat products for sorghum and millet, while important and widely documented, is only part of the story. The share of roots and tubers in total calories available from all starchy staples increased in 10 of the 15 ECOWAS countries between 1980 and 2009. In part this growth was due to the cassava revolution in some of the coastal countries such as Ghana, Nigeria and, more recently, Sierra Leone (Nweke et al., 2002), but it also reflected continued strong growth of yam production (Nweke, 2015), a sharp increase in sweet potato availability in some countries like Mali, and increases in consumption of Irish potatoes. The other striking feature was vigorous growth in per capita maize availability among most countries. 
- Increased consumption of perishables. Consumption of perishables - animalbased products, fruits and vegetables - is expanding rapidly. Along the coast, fish remains the dominant source of animal protein, although consumption of poultry, much of it imported from Latin America and Europe, has increased sharply. In the inland Sahelian countries, the dominant animal protein sources have remained red meat and dairy products. Consumption of dairy products, much of it based on imported milk powder, has also been expanding in the coastal countries. While data on horticultural production in West Africa are notoriously weak, available evidence from food balance sheets, budget consumption studies and the spread of peri-urban horticultural production all point to growing per capita consumption in recent years. The increases, particularly for fruit, have been most marked in countries with rapid economic growth, such as Cabo Verde and Ghana.

- More fats, sugar and alcoholic beverages. Over the period 1980-2009, per capita availability of fat increased in 14 of the 15 ECOWAS countries, declining only in Sierra Leone, where it initially had been highest of all the countries. Average per capita availability of alcoholic beverages (mainly beer) increased in 7 countries. The growing market for beer is offering new markets for West African farmers, as brewers in major consuming countries attempt to shift to more local raw materials, such as sorghum and cassava.

- Concerns about quality and healthfulness. The market reforms of the 1980s and 1990s, combined with rising incomes, have led to greater product differentiation in food markets. This differentiation is reflected in a broader range of formal and informal product grades and increased consumer willingness to pay for various aspects of product quality (Bricas and Seck, 2004).

\section{Implications for future food demand and for the agrifood system}

The evolutions discussed above imply that West African food systems, particularly the post-harvest components that involve assembly, wholesaling, processing, packaging, and retailing, will face rapidly growing stress in the coming decades. The demand for convenience is essentially a demand for post-harvest services to be applied to raw agricultural products in order to make them quicker and easier to prepare and consume. This implies growing demand for food processing, packaging, logistics and innovative marketing. The already heavy reliance of West Africans on the market for the majority of their food will grow even more as urbanisation continues and rural incomes increasingly diversify to include more non-farm activities. This growing reliance will put increasing strain on already stressed transport infrastructure, wholesale and retail systems, and personnel with the logistical and marketing skills to face these challenges. The strains and challenges of ensuring affordable product safety will climb as the volume of highly perishable products increases.

Table 2 presents the unweighted average income elasticities of demand for selected food products, across West Africa between 2002 and 2012. These figures are for the 10 food product categories with the highest income elasticities of demand. They provide insight into which products and services will face the most rapidly growing demand over the coming decade. Several features stand out:

1. Elasticities for half of the food categories shown for the urban areas and for all in the rural areas are equal to 1.0 or greater - i.e., as incomes grow, their demand will increase at least as fast as the growth of incomes.

2. Many of the products with high income elasticities involve substantial processing and off-farm value added. 
3. Dining outside the home (for which elasticity estimates were available for three countries) tops the list, with demand estimated to increase at twice the rate of per capita income growth in urban areas and even faster in rural areas. Strikingly, this is the category that has the highest level of post-harvest value added.

4. The lowest elasticities for any major food group (not shown in Table 2) were for millet and sorghum, suggesting that as incomes grow, their share of the starchy staples consumed in West Africa will continue to diminish.

5. Several of the top items in both rural and urban areas (dining away from home, dairy products, meat, seafood, fruits and vegetables) also involve highly perishable items, requiring tight vertical co-ordination in their respective value chains and expansion of cold chains. They are also items for which increasing consumer concerns about convenience, quality, healthfulness and food safety are central in shaping demand.

Table 2

Average income elasticities of demand for selected food products from budget consumption studies in West African countries

\begin{tabular}{|c|c|c|c|c|c|c|c|}
\hline \multicolumn{4}{|c|}{ Urban consumers } & \multicolumn{4}{|c|}{ Rural consumers } \\
\hline Rank & Item & $\begin{array}{l}\text { Average } \\
\text { income } \\
\text { elasticity }\end{array}$ & Number & Rank & Item & $\begin{array}{l}\text { Average } \\
\text { income } \\
\text { elasticity }\end{array}$ & Number \\
\hline 1 & Outside dining & 1.97 & 3 & 1 & Outside dining & 2.26 & 3 \\
\hline 2 & Dairy products & 1.38 & 8 & 2 & Meat & 1.55 & 8 \\
\hline 3 & Beverages & 1.31 & 6 & 3 & Beverages & 1.38 & 6 \\
\hline 4 & Meat & 1.24 & 8 & 4 & Dairy products & 1.38 & 8 \\
\hline 5 & Wheat products & 1.19 & 6 & 5 & Wheat products & 1.35 & 5 \\
\hline 6 & Yams & 0.92 & 4 & 6 & Yams & 1.33 & 4 \\
\hline 7 & Fruits \& vegetables & 0.89 & 8 & 7 & Rice & 1.11 & 8 \\
\hline 8 & Fish and seafood & 0.84 & 8 & 8 & Cassava & 1.07 & 4 \\
\hline 9 & Rice & 0.75 & 8 & 9 & Fruits \& vegetables & 1.07 & 8 \\
\hline 10 & Oils and oilseeds & 0.74 & 8 & 10 & Fish and seafood & 1.00 & 8 \\
\hline
\end{tabular}

Note: Figures for average income elasticities are arithmetic means of elasticities estimated from data in budget consumption studies carried out between 2002-12 in Burkina Faso, Côte d'Ivoire, Ghana, Mali, Niger, Nigeria, Senegal, and Togo. Figures shown are for the top ten food groups in terms of their average elasticities and for which data are available for at least three countries in the region.

Source: Hollinger and Staatz, 2015 and authors' calculations 
While there are some differences in the ordering of items between rural and urban areas, the items for which demand will increase the fastest with income growth are remarkably similar. It is also striking that the average estimated elasticities are uniformly higher in rural areas than in urban areas. This indicates that the diet transformation described above is not just an urban phenomenon. Although estimated per capita consumption of most of these high-value items is lower in rural areas than in urban areas (for details see Hollinger and Staatz, 2015: chapters 5-6), the high income elasticities among rural consumers indicate that as incomes rise, rural consumption patterns will increasingly come to resemble those seen in urban areas. Nonetheless, given projected patterns of continued urbanisation and income growth, demand for most of these food items is likely to grow at between two and four times faster in urban areas than in rural areas between 2010 and 2040 (Zhou and Staatz, 2016).

\section{RESPONSE OF THE FOOD SYSTEM TO CHANGING DEMAND}

$\mathbf{T}$ he response over the past 30 years from the different levels of West Africa's food system - farm-level production, food processing, retailing, and policy - to these changes in demand has been mixed.

\section{Farm-level production}

Production of most agricultural products - especially basic food staples such as rice, maize and pulses - grew vigorously since 1980, even on a per capita basis. However, for several food products with the most dynamic market demand - meat, fish, dairy, rice, vegetable oils and sugar - demand outpaced production, resulting in increased imports. In the aggregate, agricultural growth rates were generally below 6\%, the target established by the Comprehensive Africa Agriculture Development Programme (CAADP). ${ }^{4}$

Since 2009, despite the implementation of national and regional CAADP programmes, which have put heavy emphasis on production of basic staples (particularly rice), these patterns have persisted, except for rice production (Table 3). Regional totals are heavily influenced by the performance of Nigeria, which produces $50 \%$ or more of the ECOWAS volume of many agricultural products. While production of rice, maize and cassava increased rapidly across the region, production of perishables and vegetable oils, for which demand was growing rapidly, increased much more slowly (or in some cases declined), but with substantial variation between Nigeria and the rest of the ECOWAS zone (Table 3).

Output growth for most products was largely driven by area expansion (Figure 1). Land and labour productivities, while increasing in recent years (OECD/SWAC, 2013), are still well below global benchmarks. For example, while yield growth has accounted for $16 \%$ of the growth in agricultural production in West Africa since the mid 1980's, such yield increases account for $80 \%$ of production growth for developing countries as a whole (Figure 1). Intensification has been largely confined to horticultural and livestock production in peri-urban areas, irrigated rice in some areas and a few export crops.

The rice sector, which is the focus of the most intense government investment and input subsidies since the food crisis of 2008 (e.g., through the ECOWAS-sponsored regional rice offensive), has been a notable exception to these patterns in recent years. AfricaRice (cited in ECOWAS Commission et al., 2015) reports that since 2008, $71 \%$ of the growth in rice production in the region has been due to yield increases, compared to only $24 \%$ prior to this time. A key policy question is whether the high level of input subsidies that contributed to this yield growth is financially sustainable. 
Table 3

Annual growth rates of production, ECOWAS region: 2009-13

\begin{tabular}{|l|r|r|l|}
\hline Commodity & ECOWAS & Nigeria & \multicolumn{2}{l|}{$\begin{array}{l}\text { ECOWAS excl. } \\
\text { Nigeria }\end{array}$} \\
\hline Rice & $7.9 \%$ & $7.9 \%$ & $7.9 \%$ \\
\hline Cassava & $7.6 \%$ & $9.5 \%$ & $4.4 \%$ \\
\hline Maize & $6.6 \%$ & $8.5 \%$ & $4.6 \%$ \\
\hline Fruits \& vegetables & $3.2 \%$ & $2.6 \%$ & $4.1 \%$ \\
\hline Milk & $-0.6 \%$ & $5.2 \%$ & $-1.5 \%$ \\
\hline Vegetable oils & $-0.8 \%$ & $-2.6 \%$ & $1.8 \%$ \\
\hline Meat & $-2.6 \%$ & $-7.3 \%$ & $1.9 \%$ \\
\hline
\end{tabular}

Source: Authors' calculation, based on FAOSTAT data

Figure 1

Contribution of area and yield to output growth in cereals, 1980-89 to 2000-09 (\%)

$\square$ Area effect $\quad \square$ Yield effect $\quad$ Interaction effect

100

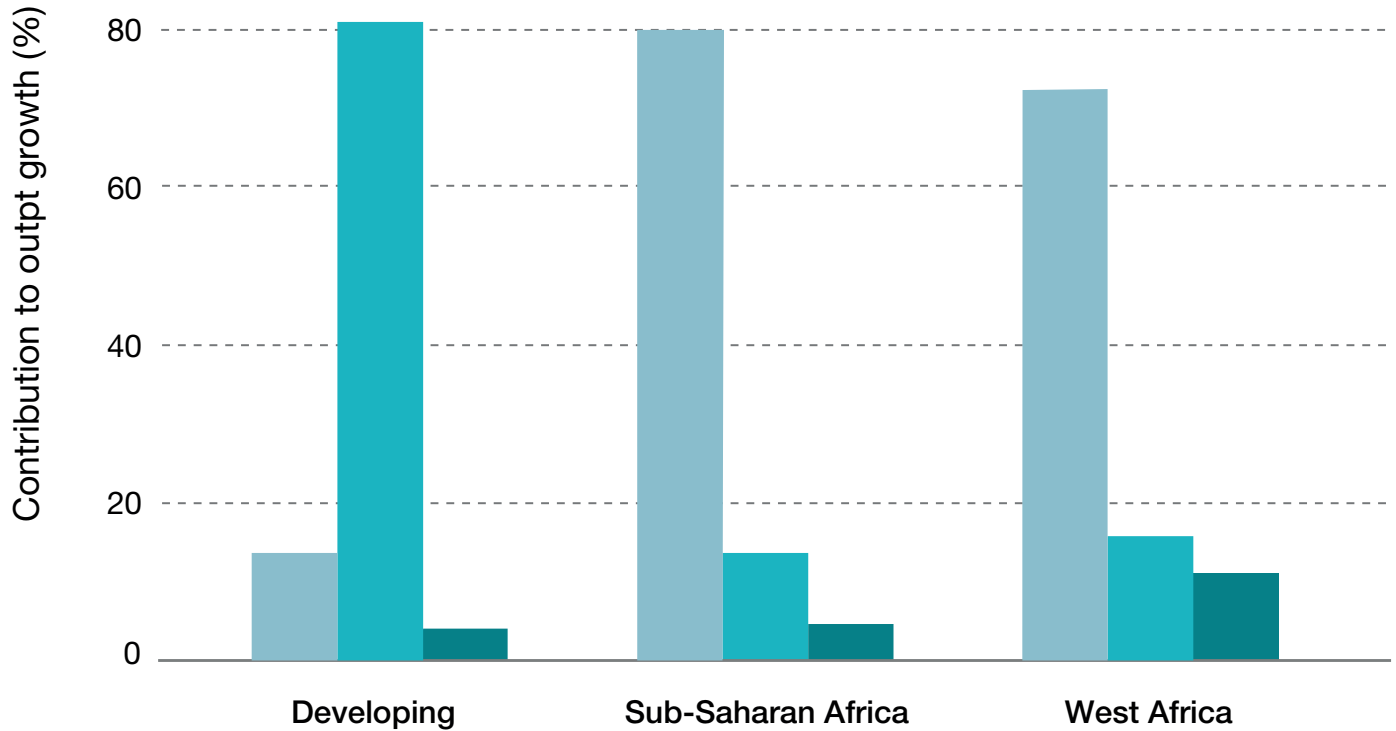

Note: The figure shows the contribution of expansion of area ("area effect"), yield increases ("yield effect") and the interaction between area and yield to the growth in production between the decades of 1980-89 and 2000-09. Decade-wide averages are used.

Source: Authors' calculations, based on FAOSTAT data 
Factors that have limited production and productivity growth over the past 30 years have been widely discussed in the literature (Hollinger and Staatz, 2015). They include, among other things, market access and infrastructure-related constraints; weak access to improved inputs, technologies and support services (caused in part by underinvestment in agricultural research and extension); weak rural financial services; elevated production and market risks (ranging from weather-based risks to insecure land tenure and volatile world markets) and inadequate tools to manage them; policy volatility (e.g. stop-go policy on import bans); and weak investments in critical public goods such as rule of law, rural education and vocational training.

The above factors have contributed to the erosion of West African producers' market shares for many products on domestic and export markets. On an aggregate level, while food and other agricultural exports grew strongly, imports grew even faster. As a result, West Africa's food trade balances with the rest of the world have been negative since the beginning of this millennium. Food imports are centred on a limited number of commodity groups for which demand is growing rapidly, with rice, wheat, vegetable oils, fish, dairy products and sugar accounting for over $80 \%$ of the aggregate value of food imports. At the same time self-sufficiency ratios for many basic food staples have declined only modestly and remain high (on the order of 80\%) for the region as a whole (Hollinger and Staatz, 2015).

\section{Food processing and linked value chains}

Most agricultural value chains remain plagued by poor co-ordination and limited trust among actors, exacerbated by underdeveloped marketing and transport infrastructure, and erratic electricity supplies. Scattered production and small marketed volumes - a consequence of the extensive growth model - lead to higher cost for product assembly, sorting and grading. These factors drive up risks and costs facing value-chain actors and limit the transmission of information and incentives from consumers to producers. For example, unreliable electricity supply from the grid has forced many processors to install costly back-up generators. These costs fall heavily on processors of perishable commodities. Given these weaknesses, retailers and wholesalers often revert to imports to meet urban demand. Likewise, large agro processors targeting some of the most dynamic domestic market segments - e.g., pasta, bread, bakery products, dairy products and fruit juices - rely heavily on imported raw materials. While the region lacks comparative advantages for large-scale import substitution of some of these raw materials (e.g. wheat and milk), in many cases local raw materials have been used successfully in West African agro-processing (e.g. sorghum or cassava [Box 1] for beer and bread), showing the potential for import substitution if supply chains can be organised effectively.

\section{Food retailers}

The response of retailers to the evolving demand has varied across different segments of the food retailing sector. Retailing is still dominated by traditional marketing channels, including open markets, traditional wholesalers, neighbourhood stores and food vendors. The traditional retailing system has responded to the evolving demand by greatly expanding both the number of retailers and the scope of their activities. Most striking has been the rapid expansion of street-food vendors, responding to the need of low-income urban workers for fast, convenient meals. Retailers have also expanded their sale of processed staples and imported canned and dry goods. Traditional open markets have struggled to cope with the burgeoning growth of demand, and are often characterised by crowded and unsanitary conditions. Urban congestion, weak public transport systems and erratic electricity service (which hinders the spread of refrigerators among consumers and hence forces them to shop frequently for perishables) have helped traditional neighbourhood retailers maintain a substantial share of the consumer market compared to larger modern retailers. 
However, there are signs that the growth of the modern food retail segment (supermarkets and modern fast-food retailers) has accelerated in recent years. In particular major urban areas have seen strong growth in supermarkets and quick-service restaurant chains and outlets. Over the past five years the sector has seen the entry of regional and international players into both the modern grocery and food services sectors, particularly in Côte d'Ivoire, Ghana, Nigeria and Senegal. Yet, modern food retailing remains underdeveloped relative to the market size, urbanisation levels and economic dynamism of these countries. The pace of growth and expansion will not only depend on the overall economic dynamism in the region, but also on the ability of investors to overcome the challenges related to the business and operating environments, such as access to finance and real estate, and underdeveloped domestic supply chains. Even in the case of modest growth, the development of domestic supply chains could enable producers to access higher value market segments.

$\frac{\text { Box } 1}{\text { West Africa's unfinished cassava revolution }}$

Between 1980 and 2014, cassava production in West Africa more than quintupled, driven by technological change and rapid growth in demand for processed cassava products such as gari and attiéké. On the supply side, the International Institute of Tropical Agriculture in Ibadan, working closely with national researchers and farmers in Nigeria, developed disease-resistant varieties of cassava whose yields were $40 \%$ higher than traditional varieties even when they received no fertilizer. This cropbreeding work was coupled with the design of improved, small-scale processing equipment, particularly graters, that increased the productivity of entrepreneurs - mainly women - engaged in transforming cassava roots into ready-to-eat products such as gari and attiéké. On the demand side, gari and attiéké filled a growing niche in the demand for fast foods by time-poor urban consumers. Gari, a dried, roasted form of cassava that can be eaten as a snack or prepared quickly with hot water, is a quintessential African fast food and rice substitute. Attiéké, made from fermented, grated cassava, is widely consumed in Côte d'lvoire and is increasingly exported to the Sahelian countries.

These developments led to the transformation of cassava from a lowyielding famine-reserve crop to a high-yielding cash crop, in the process expanding farmers' incomes and generating tens of thousands of jobs for small-scale processors. The "cassava revolution" began in Nigeria, spread subsequently to Ghana and Côte d'Ivoire and more recently expanded to countries like Sierra Leone, where production grew at an annual rate of $14 \%$ over the $2004-13$ decade. As consumers' incomes rise, however, one can anticipate increasing demand for better hygiene and quality control of the products coming from small-scale processors, leading to the need for further investments in skills, equipment and packaging.

Efforts to take the next step in this revolution, moving cassava from a cash crop directed mainly at urban consumers to an industrial crop producing products such as starch, flour, syrups, and ethanol, have had a much more uneven record to date. Industrial processing to produce products such as high-quality cassava flour (to substitute for wheat flour in bakery products) and cassava starch and cake as an input into beer production have often foundered. Industrial plants need to draw roots from a large catchment area (as much as a $30 \mathrm{~km}$ diameter) in order to operate near capacity. The poor state of rural roads and the bulky nature of cassava roots, which are 2/3 water by weight, raises industrialists' assembly costs above those of individual small-scale processors. The latter only need to acquire roots locally, allowing them frequently to out-compete industrialists for raw materials. Large-scale processors are currently developing in-the-field processing of intermediate products (e.g., cassava chips and cassava cake) that are less costly to transport, combined with contract farming arrangements to ensure farmers a more secure market, in an effort to push West Africa's cassava revolution to its next level.

Sources: Nweke et al. (2002), Hollinger and Staatz (2015), FA0 (2016).

\section{Policy response: ECOWAP/CAADP}

The policy response to these changes, both by West African governments and their development partners, has been to put a much stronger and more co-ordinated emphasis on agricultural development since the early 2000s. This included the development of regional (as opposed to just national) agricultural policies, beginning with the West African Economic and Monetary Union (UEMOA) in 2001 and ECOWAS in 2005. The ECOWAS Agricultural Policy (ECOWAP), launched in 2005, became the West African regional component of CAADP. Under this programme, each of the ECOWAS member states developed its own national agricultural investment plan (NAIP), based on a common approach supported financially by the Community, with technical support from the International Food Policy Research Institute (IFPRI). ECOWAS simultaneously 
developed a regional investment plan (RAIP) and associated policies to deal with issues of regional agricultural integration, particularly spillovers across national borders (such as management of shared natural resources) and areas where large scale economies can be captured through greater co-operation (as in regional programmes of agricultural research). A key aim of ECOWAP/CAADP has been to move agricultural development efforts from a project-driven approach to a sector-wide approach, wherein all major stakeholders (private sector, government, civil society, development partners) agree on an overall approach and co-ordinate their actions around that approach. ${ }^{5}$

The ECOWAP/CAADP process has been more inclusive than previous efforts and has given agricultural development greater visibility in the political agenda of many West African countries. It has also moved countries towards more sector-wide and regionally consistent agricultural policy and programme development. However, the first phase of NAIPs and RAIPs had limited elements which responded to the changes in consumer demand discussed above.

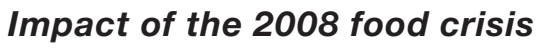

The 2008 food crisis, and particularly the spike in world rice prices, strongly influenced the design of the first generation of ECOWAP/CAADP programmes. In response to the crisis, many governments launched emergency agricultural production programmes (such as Mali's "Initiative Riz" and Senegal's "Grand Offensive Agricole pour la Nourriture et l'Abondance") aimed at rapidly increasing production of staple foods, particularly rice, often through the heavy use of input subsidies. Consequently, several of the NAIPs had to be built around these programmes that had already been launched and that absorbed sizeable financial, institutional and human resources, which were consequently unavailable for longer-term structural investments and policy reforms.

\section{Relatively light focus on perishable products}

Although demand for animal-based products is increasing rapidly, the share of budget resources allocated to livestock and fisheries in the NAIPs and RAIPs is typically small relative to crop production. In Senegal, for example, the NAIP allocated 11\% of its budget to livestock and 5\% to fisheries, compared to 69\% for crops. Similarly, in part perhaps to keep the scope of activities manageable in the initial phase of CAADP, relatively little attention was given to horticultural production, despite the growing demand for such products.

\section{Strong emphasis on rapid production increases at the farm level}

Most investment programmes placed heavy emphasis at the farm level relative to postharvest segments of the food system. For example, the budget for the first 5 -year phase of Senegal's NAIP allocated 59\% of its resources to a component aimed at improving productivity at the farm level. This compared with $5 \%$ allocated to improving market access, $1 \%$ to strengthening the capacity of various stakeholders such as farmer groups and interprofessional organisations, and $0.6 \%$ each for improving processing and financing agricultural research (Figure 2). Because of the emphasis on increasing farm-level production rapidly, the budget allocated only $31 \%$ to investing in structural issues (investment costs) with the rest going to recurrent costs, of which more than two thirds to input subsidies. 
Figure 2

Allocation of Senegal's NAIP by programme (2011-2015)

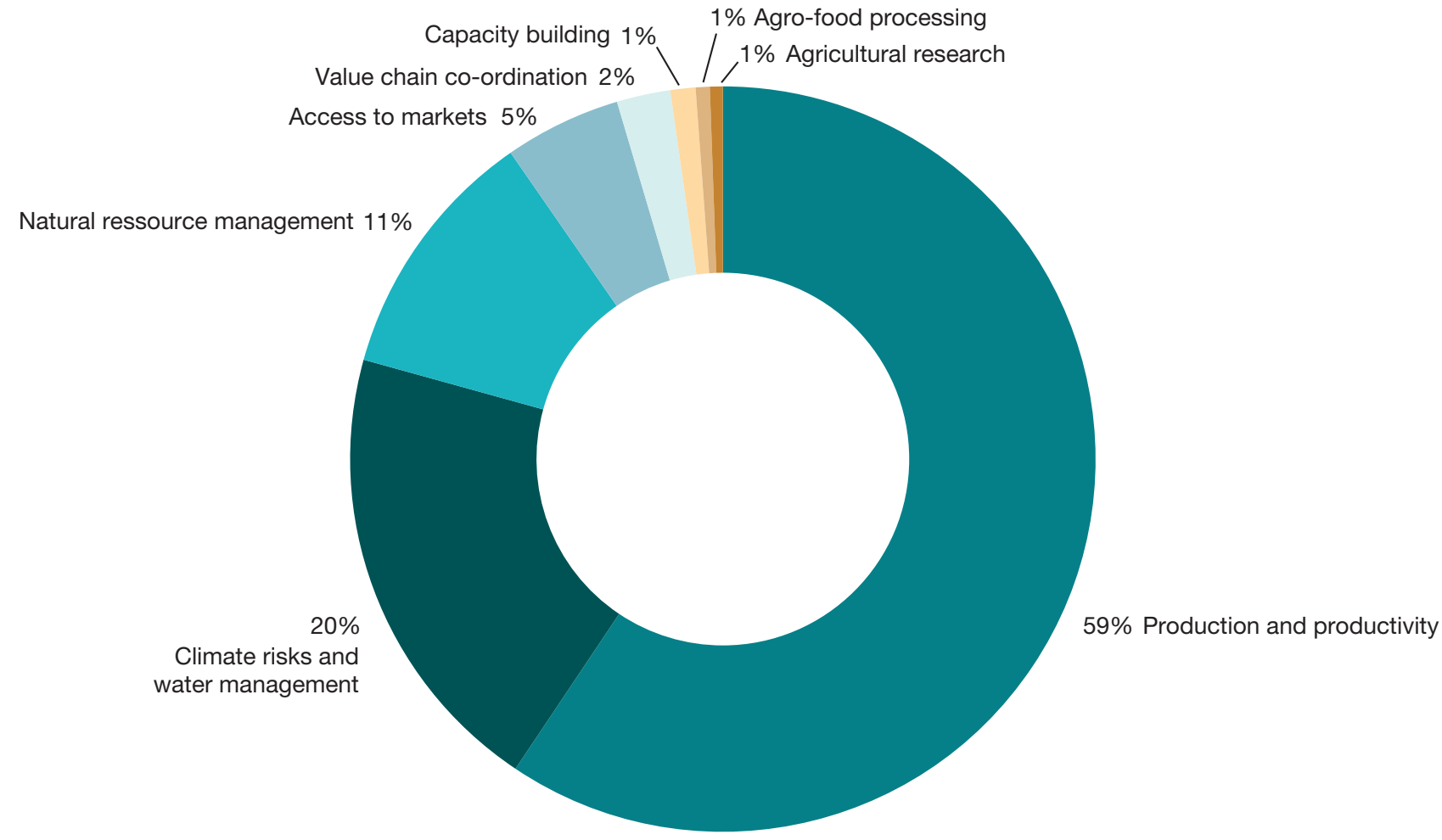

Source: NAIP Senegal, Plan d'investissement agricole 2011-15

\section{Little emphasis on market development and capacity building}

Beyond the first step in the marketing chain, where farmers sell their products to initial product aggregators (the farmer-first handler level), there is little emphasis on market development and capacity-building. The main focus in most market access components of NAIPs and RAIPs was on improving farmer-first handler links, particularly on strengthening the activities of farmer organisations. Budget allocations to other components of the food system were much lighter, such as for improved wholesaling, processing, food safety, research, extension, and human capital development, all of which will be increasingly critical for a successful transformation of the system. Similarly, while many NAIPs emphasise the need for capacity development, their focus is primarily on farmer organisations and inter-professional organisations that link farmers with wholesalers and input providers. The plans devote far fewer resources to the capacity-strengthening needs of other food-system stakeholders such as SMEs in processing and marketing or for the need to reform agricultural education systems to help develop the skills needed for a 21st century food system.

\section{Few explicit links to industrial investment programmes}

There is also relatively little explicit articulation, at both the national and regional levels, between agricultural investment programmes and industrial investment programmes, although the latter generally include a focus on agro-processing. The same applies, with some exceptions, to government institutions charged with programme co-ordination, implementation and monitoring. This lack of policy co-ordination has done little to change the preference of large processors to use imported raw materials instead of domestic sourcing. 


\section{Very ambitious production goals and reliance on external financing}

Most of the NAIPs set extremely ambitious production goals to be met over a short period of time. Achieving such objectives will require large increases in investments and recurrent expenditures in the agricultural sector. Consequently, the NAIP and RAIP budgets are heavily dependent on hoped-for increases in donor funding. Amongst the NAIPs, the gap between planned expenditures and funding currently on hand ranged from 30\% (in Niger, where most of the current funding was already supported by donors) to $90 \%$ in Gambia. The RAIP budget called for ECOWAS to provide 15\% of the total funding, with the rest provided externally (Hollinger and Staatz, 2015). By 2015, however, ECOWAS had succeeded in mobilising less than $10 \%$ of its share of the funding, and donor funding was largely concentrated on trying to establish monitoring and evaluation capacity.

Many of these shortcomings have been recognised within the region. They were widely discussed among stakeholders during 2015 as ECOWAS launched a participatory process aimed at developing the next 10-year phase of ECOWAP. Among the key action points highlighted for the 2016-25 phase of the programme and summarised at the November 2015 "ECOWAP +10" conference in Dakar, were the following:

- Place greater emphasis on the off-farm components of the food system, with a particular focus on improving vertical co-ordination throughout the system, for example, through a greater use of contracting among value-chain participants and the creation and strengthening of regional inter-professional organisations.

- $\quad$ Place more emphasis on value chains dealing with perishable products, particularly fruits, vegetables, milk and fish.

- $\quad$ Promote job creation throughout the food system by focusing on structural problems such as improved vocational training, strengthened access to better technologies through research and outreach, and by addressing issues of land tenure and access to financing that would otherwise limit entry into farming and agro-processing.

- A reallocation of efforts from programme design to programme implementation, monitoring and evaluation.

\section{POLICY IMPLICATIONS AND RECOMMENDATIONS}

W est Africa's rapidly growing and changing pattern of food consumption offers great opportunities and challenges for stimulating greater internally generated growth within ECOWAS, more job creation and healthier diets. Developing a stronger understanding of how consumer demands are changing and adapting policies to respond to these demands will be crucial to mitigating the challenges and exploiting the opportunities.

\section{The design of food system interventions starts with the consumer}

In increasingly buyer-driven agricultural value chains, consumers are the ultimate financiers of the food system. Therefore, an improved understanding of their evolving preferences in terms of quality, convenience, safety and other food attributes is a prerequisite for producers to respond better to demand trends and successfully compete with imports. This approach requires improved market information on specific product attributes, more effective grades and standards and better co-ordination among agricultural value-chain actors. At the same time, consumers of all income brackets need better information on the nutritional qualities and health implications of different food products in order to make informed purchasing decisions. Information on nutritious local foods should be made broadly available and the production and marketing of such food products promoted. 
The rising middle class will continue to search for safer and higher value-added foods. Strengthening national food safety systems is therefore important not only for public health but also to enhance consumers' trust in domestic food products, countervailing the tendency to rely on international brands for their perceived higher food safety levels. Increased capacity to meet higher food safety standards is also critical for promoting exports into higher value and niche markets.

Three-quarters of the West African population, however, still lives on less than USD 2 per day, making the price of food a major determinant of their well-being. Therefore, increasing efficiency throughout the food system is paramount, being the only economically sustainable way to enhance consumers' access to lower-priced foods while simultaneously raising producers' incomes and competitiveness. Attempts to support farmers and processors through import restrictions (e.g. tariffs, quotas or trade bans) are harmful for the majority of consumers, both urban and increasingly rural. Since large-scale consumer subsidies are beyond the fiscal means of West African countries, policies and investments should be centred on improving productivity and efficiency throughout the food system in order to reduce the unit costs of production and marketing.

\section{System governance and policy implementation are critical}

Transforming West Africa's food system to respond to rapidly changing consumer demand depends not just on policy design, but rests critically on system governance and policy implementation by public and private actors alike.

A critical element in system governance is improving the overall business climate within which the agrifood system operates in the region. While in the past, West African governments often envisioned agricultural development as a state-led effort, most productive investments in the sector have come from private actors, from farmers and traders to processors and providers of support services, and will continue to do so in the future. An improved policy environment, critical public investments and strengthened policy implementation are key to stimulating sustainable, productivity-enhancing private investments for broad-based growth. In addition, the predictability of government actions is critical to instil trust in private stakeholders. Interventions in input and output markets must be rules-based rather than ad hoc and should be based on a broadly shared consensus on the public sector's roles and priorities in the agrifood system. Multi-stakeholder processes and mutual accountability frameworks in the formulation, implementation, monitoring and evaluation of policies and programmes are instrumental in building this consensus. Trust in public sector interventions will also depend on improving the capacity to implement and evaluate policies at local, national and regional levels. 


\section{Key policy recommendations}

Six elements are key to increasing food system efficiency in order to address the challenges discussed above:

\section{Improve the quality of public investment}

ECOWAS/CAADP has stressed the importance of increasing the level of public investments in agriculture up to the CAADP target of 10\% of the government budget. While the level of investment is important, a better investment mix is even more important. Public expenditures need to focus more than in the past on improving the performance of the off-farm elements of the food system (such as marketing, processing, packaging and logistics), which are increasingly under stress. At the farm level, public expenditures need to emphasize investments in infrastructure, technology development and farmer support services, rather than just input subsidies, in order to boost long-term productivity.

\section{Improve rural-urban linkages and intraregional trade}

The strongest growth in demand for food will continue to come from urban areas, especially in coastal countries. Investments in transport and marketing infrastructure to improve market access, reduce post-harvest losses and expand input markets and support services in the rural hinterland will be critical in allowing West African farmers to capture a large share of this growing demand. Investments in hard infrastructure should also be complemented by improvements in institutional and regulatory soft infrastructure. Examples include reforming rules restricting competition in the trucking industry that drive up transport costs, improving systems of contracting and contract enforcement among actors at all levels in the food system, and designing and implementing grades and standards that provide incentives to producers to invest in upgrading product quality.

\section{Deepen regional integration}

Greater regional integration is the key to addressing many of the challenges discussed above. Free movement of goods and services reduces price volatility and allows the development of cross-border value chains. Moreover, to be competitive in a wide range of products with large global actors such as Brazil, China and India, West African agriculture needs to capture some of the scale economies those countries enjoy in agricultural research, input markets and technology development, among others. To do so, the region requires more harmonised grades and standards for agricultural inputs and outputs, common procedures for approval and reviews of improved varieties, regionally co-ordinated systems of agricultural research and higher education, and removal of restrictions that limit agro processors from sourcing agricultural products across national borders.

\section{Build the skills base for West Africa's food system in the 21st century}

Transforming West Africa's food system into a modern driver of economic growth will require a profoundly different set of skills at all levels of the systems than currently exist in most ECOWAS countries. Needed actions include strengthening basic literacy, particularly at the farm level; linking curricula (e.g. in mathematics and biology) in primary and secondary schools to applications in farming and agro-industry; expanding vocational education programmes in the large range of technical skills needed by workers in a modern food system; attracting more girls to the sciences, given the important role that women play in West African agriculture; and broadening undergraduate university education in agricultural faculties to include fields that are crucial to downstream areas of the food system, such as food science, packaging and logistics. 


\section{Improve policy co-ordination}

Due to the growing importance of the off-farm segments of West Africa's food system and the environmental, nutritional and health implications of agricultural growth, food system policy-making needs to move beyond the traditional confines of agricultural ministries. Many of the key constraints to more rapid and inclusive food system growth in the region are outside of the agriculture sector. Addressing these requires improved policy co-ordination and harmonisation between (i) sectors (agriculture, health, trade, energy, industry, transport); (ii) actors (farmers, consumers, traders, processors); and (iii) along different levels of government, from supra-national to local levels. The ECOWAS Commission has made some steps in this direction through the creation of the ECOWAS Inter-departmental Committee on Food and Agriculture, which includes representatives from ECOWAS departments outside of agriculture (such as trade and industry, infrastructure and energy) that supervise the regional programmes which are critical to the development of the agrifood system. As of the end of 2015, however, the Committee had yet to meet. Similar co-ordination efforts exist in a few countries, such as Ghana, but much remains to be done.

\section{Improve policy implementation}

Improving policy implementation means producing better data and a stronger evidence base for policies, investing in the capacities of key agencies and organisations charged with implementation, as well as ensuring the overall coherence of policies and programmes. Better policy implementation in West Africa therefore requires: (i) strengthening the analytic, monitoring and evaluation capacities of key agencies and organisations charged with policy implementation (ii) improving the databases upon which policy decisions are made, as well as the capacity of decision-makers to use these data; (iii) better aligning the interests of different countries, individual actors and the region as a whole. The existence of robust national and regional private sector and civil-society stakeholder groups and a free press act as counterweights to inefficient policy implementation and rent seeking, and contribute towards more transparent and effective implementation.

\section{CONCLUSION}

W est Africa faces the challenge of increasing the overall volume of its food production by at least $4.6 \%$ per year through 2020 and by 3.5 - 4\% for several decades thereafter while at the same time dramatically changing the mix of production to respond to rapidly evolving dietary preferences. Bridging the gap between demand and supply for staples such as rice will continue to be a challenge in absolute terms for most West African countries. If current trends continue, however, the demand for other food groups - meats, dairy products, fish, vegetable oils and fruits and vegetables - and for processing and marketing services from the post-harvest components of the food system will increase at an even faster rate. Food policy and capacity building in West Africa therefore need to give greater emphasis to a broader range of commodities and to post-harvest services, such as bulking, grading, wholesaling, processing, packaging and retailing. Many of the products for which demand is rising most rapidly are perishable and require tightly co-ordinated marketing systems and key investments such as cold chains to link producers effectively to these growing demands. The good news is that if such systems can be developed, the production, processing and marketing of these products is much more labour-intensive than those of cereals, offering the opportunity to create many new jobs. The challenge for policy makers is to help create the economic and policy environment that will allow West Africans to capitalize on this opportunity. 


\section{NOTES}

1. This is the UNDESA "median variant" projection for the ECOWAS countries in 2050 .

2. These figures are the UNDESA (2015) medium-scenario population projections for the region. Under its high-growth scenario, the population growth rate would be $2.4 \%$ per year in 2035-40.

3. Income elasticities of demand are a measure of how quickly demand for a product increases as incomes rise. If demand grows at the same rate as income growth, the elasticity has a value of 1.0; product demands that grow more than proportionally with higher incomes have an elasticity greater than one, and those that grow less quickly than income have a value below one. As shown below, estimates of the income elasticity of demand for food in West Africa are close to 1.0. In this example, total demand would increase by the population growth rate + the per capita income growth rate times the income elasticity of demand. For the period through 2020, the total growth rate for food would therefore be $2.5 \%+3 \% \times 0.7=4.6 \%$.

4. The average annual rate of growth of agriculture value added in the ECOWAS zone was $5.7 \%$ over the period 1995-2003, but then fell to 4.2\% over the period 2008-14 (Badiane and Makombe, 2015:203)

5. For an extensive discussion of the ECOWAP/CAADP programmes, see Hollinger and Staatz, 2015: chapters 11 and 12; ECOWAS Commission, 2015 and Oxfam, 2015.

\section{REFERENCES}

AfDB (2011a), Africa in 50 years' time: The road to inclusive growth, Tunis.

AfDB (2011b), The middle of the pyramid: Dynamics of the middle class in Africa, Market Brief, African Development Bank.

Allen, T. and P. Heinrigs (2016), "Emerging Opportunities in the West African Food Economy", West African Papers, No. 1, OECD Publishing, Paris, http://dx.doi.org/10.1787/5jlvfj4968jb-en.

Badiane, O. and T. Makombe (eds.) (2014), Beyond a Middle Income Africa: Transforming African Economies for Sustained Growth with Rising Employment and Incomes, ReSAKSS Annual Trends and Outlook Report, International Food Policy Research Institute (IFPRI), Washington.

Bricas, N. (2006), "Les marchés alimentaires urbains en plein développement », Grain de sel, No. 34-35, March-August.

Bricas, N., C. Tchamda and M-C. Thirion (2013), "Consommation alimentaire en Afrique de l'Ouest et Centrale : les productions locales tirées par la demande urbaine, mais les villes restent dépendantes des importations de riz et de blé ", Le Déméter, Economie et stratégies agricoles, 2014, pp. 125-142.

Bricas, N. and P.A. Seck (2004) "L'alimentation des villes du Sud : les raisons de craindre et d'espérer », Cahiers Agricultures, Vol. 10, pp. 10-14.

Delgado, C.L. and C.P.J. Miller (1985), "Changing food patterns in West Africa: Implications for Policy Research", Food Policy, Vol. 10/1, pp.55-62.

Denis, E. and F. Moriconi-Ebrard (2008), Africapolis: Urbanization trends 1950-2020, a geostatistical approach, West Africa, Laboratoire SEDET (Developing Societies in Space and Time), CNRS/Université Paris Diderot, Agence française de développement (AFD), Paris.

Eberhard, A. et al. (2011), Africa's Power Infrastructure: Investment, Integration, Efficiency, World Bank, Washington.

ECOWAS Commission (2015), Agriculture and Food in West Africa: Trends, Perfomances and Agricultural Policies, Abuja.

ECOWAS Commission, UEMOA Commission and NEPAD Planning and Coordinating Agency (2015), "Programme d'appui à la mise en œuvre de l'Offensive régionale pour la relance durable et soutenue de la riziculture en Afrique de l'Ouest : Evolution récente du secteur rizicole ouest africaine, opportunités et défis ", document prepared for the international business meeting on the West Africa Rice Initiative, 27-29 November, Dakar.

FAO (2016), FAOSTAT Statistics Database, http://faostat3.fao.org/.

Hitimana, L. et al. (2009), "Harmonization of West African settlement data", West African Futures Note, No. 2, Sahel and West Africa Club/OECD, Paris.

Hollinger, F. and J.M. Staatz (eds.) (2015), Agricultural Growth in West Africa: Market and Policy Drivers, African Development Bank and FAO, Rome.

Me-Nsope, N.M. and J.M. Staatz (2015), "Changes in Per Capita Food Availability in West Africa: Implications for Agricultural Market Development”, SRAI 2 Policy Brief No. 2, Michigan State University Press, East Lansing, http://fsg.afre.msu.edu/srai2/Policy_Synthesis_SRAI_2_FBS_ analysis_final.pdf.

Moriconi-Ebrard, F., D. Harre and P. Heinrigs (2016), Urbanisation Dynamics in West Africa 1950-2010: Africapolis I, 2015 Update, OECD Publishing, Paris, http://dx.doi.org/10.1787/9789264252233-en. 
Nweke, F. (2015), Yam in West Africa: Food, Money and More, Michigan State University Press. East Lansing.

Nweke, F.I., D.S.C. Spencer and J.K. Lynam (2002), The cassava transformation: Africa's best-kept secret, Michigan State University Press, East Lansing.

OECD/SWAC (2013), Settlement, Market and Food Security, OECD Publishing, Paris, http://dx.doi.org/10.1787/9789264187443-en.

OXFAM (2015), ECOWAP: A Fragmented Policy, OXFAM Briefing Paper, Oxford, UK, November.

Potts, D. (2012), "Challenging the Myths of Urban Dynamics in Sub-Saharan Africa: The Evidence from Nigeria", World Development, Vol. 40/ 7, pp. 1382-1393.

Potts, D. (2009), "The slowing of sub-Saharan Africa's urbanization: Evidence and implications for urban livelihoods", Environment \& Urbanization, Vol 21/1, pp. 253-259.

Radelet, S.C. (2015), The Great Surge: The Ascent of the Developing World, Simon and Schuster, New York.

Reardon, T. et al. (2015), "Transformation of African Agrifood Systems in the New Era of Rapid Urbanization and the Emergence of a Middle Class", in Beyond a Middle Income Africa: Transforming African Economies for Sustained Growth with Rising Employment and Incomes, ReSAKSS Annual Trends and Outlook Report, International Food Policy Research Institute (IFPRI), Washington.

Reardon, T., T. Thiombiano and C. Delgado (1998), "Substitution of Imported for Traditional Cereals in Household Food Consumption in Ouagadougou, Burkina Faso", IFPRI Research Report, International Food Policy Research Institute (IFPRI), Washington.

Rogers, B. L. and M. Lowdermilk (1991), "Price policy and food consumption in urban Mali", Food Policy, Vol. 16/6, pp. 461-473.

UNDESA (2015), World population prospects, 2015 revision, United Nations Department of Economic and Social Affairs (UNDESA), http://esa.un.org/unpd/wpp/.

World Bank (2011), Africa development indicators (database), http://data.worldbank.org/datacatalog/africa-development-indicators (accessed on 1 July 2012).

World Bank, (2016), World development indicators (database), http://databank.worldbank. org/data/reports.aspx?source=world-development-indicators\&preview=on (accessed on 3 October 2016).

Zhou, Y. and J. Staatz (2016), "Projected demand and supply for various foods in West Africa: Implications for investments and food policy", Food Policy, Vol. 6, pp. 198-212. 


\section{ALSO IN THE WEST AFRICAN PAPERS SERIES:}

Allen, T. and P. Heinrigs (2016), "Emerging Opportunities in the West African Food Economy", West African Papers, No. 1, OECD Publishing, Paris.

http://dx.doi.org/10.1787/5jlvfj4968jb-en

Lewis, K. and C. Buontempo (2016), “Climate Impacts in the Sahel and West Africa: The Role of Climate Science in Policy Making", West African Papers, No. 2, OECD Publishing, Paris. http://dx.doi.org/10.1787/5jlsmktwjcd0-en

Gnisci, D. (2016), “Women's Roles in the West African Food System: Implications and Prospects for Food Security and Resilience", West African Papers, No. 3, OECD Publishing, Paris. http://dx.doi.org/10.1787/5jlpl4mh1hxn-en

For more information on the series, please contact: swac.contact@oecd.org 